\title{
Electromyographic Measurement of Textural Changes of Foodstuffs during Chewing
}

\author{
Hiroko Sakamoto, Tsutomu Harada, Takashi Matsukubo, ${ }^{*}$ \\ Yoshinori TAKAESU* and Masakazu TAZAKI** \\ Central Research Laboratories, Ajinomoto Co., Inc., 1-I Suzuki-cho, \\ Kawasaki-ku, Kawasaki 210, Japan \\ * Department of Preventive and Community Dentistry, Tokyo Dental College, \\ 2-1-1 Masago, Chiba 260, Japan \\ ** Department of Physiology, Tokyo Dental College, \\ 2-1-1 Masago, Chiba 260, Japan \\ Received March 22, 1989
}

\begin{abstract}
We have attempted to develop an intraoral method which can measure the textural changes in foodstuffs during chewing by using electromyography (EMG). Forty-three foodstuffs with variable textural attributes were used.

Total chewing energy for these foodstuffs during chewing varied from 3 to 108 for the masseter muscle and 13 to 154 for the digastric muscle, respectively. Large differences in total chewing energy could be observed by EMG among the foodstuffs. The chewing energy for many foodstuffs revealed distinct differences throughout the chewing process. Foodstuffs could be categorized into six groups according to the changing patterns of chewing energy. EMG data and the number of strokes were influenced by masticatory index and salivary flow rate.
\end{abstract}

Food texture is an important property of processed foods; it often determines quality and acceptability. Texture can often be evaluated by instrumental measurements. Many investigators have already tried to evaluate texture objective by extraoral measurements. They have also shown that hardness or firmness, which we perceive sensorily on the first bite, can be well measured objectively. ${ }^{1,2)}$ However, these conventional techniques always correlate only weakly with subjective descriptions, due to the heterogeneity of many foods and textural changes during chewing. ${ }^{3 \sim 5)}$

In general, food requires sequential manipulation with mastication to break down solids and mix them with saliva for swallowing. That is why studies on physico-chemical changes of foodstuffs during chewing are needed to measure the changes of textural perception. ${ }^{6}$ )

In previous textural studies of processed foods, the differences in texture appeared to influence both the secretion of saliva and mastication time. ${ }^{7)}$ Conventional instrumental techniques which measure extraoral attributes do not satisfactorily imitate such factors as oral motion and the effects of saliva. Electromyography (EMG) gives a direct measure of muscle activity ${ }^{8)}$ such as that required for chewing foods. Electromyographic approaches have been used in attempt to evaluate the characteristics of foodstuffs or evaluate the influence of food characteristics on chewing patterns. ${ }^{3,9 \sim 13)}$

In this study, we have attempted to develop an intraoral method which can measure the textural changes in foodstuffs during chewing by using EMG.

\section{Materials and Methods}

Foodstuffs. Forty-three processed foods obtained commercially were used throughout this study (Table I).

Sensory analysis. Sensory analysis was done by the procedure already described by Kowata et al. ${ }^{7)}$ Trained panelists in our laboratories participated in this study. The 
Table I. List of Foodstuffs Used in This Study

\begin{tabular}{|c|c|c|}
\hline Food group & Name & Manufacture or sales agent \\
\hline Fish and Shellfish & $\begin{array}{l}\text { Dried squid } \\
\text { Smoked scallop } \\
\text { Smoked bonito } \\
\text { Smoked cuttlefish } \\
\text { Jellyfish } \\
\text { Raw squid } \\
\text { Parched small sardine } \\
\text { Sardine jerky } \\
\text { Surimi sausage } \\
\text { Tsumire (boiled fish paste) } \\
\text { Fish cake }\end{array}$ & $\begin{array}{l}\text { Hakodate High-Sea Fishery Co., Inc. } \\
\text { Saeki } \\
\text { Ando Fishery Co., Inc. } \\
\text { Jokki Co., Inc. } \\
\text { Yoshinaga Products Co., Inc. } \\
\text { Yoshikawa Fishery Co., Inc. } \\
\text { Natural Food Center Head Office Co., Inc. } \\
\text { Natural House Co., Inc. } \\
\text { Nippon Ham Co., Inc. } \\
\text { Kibun Co., Inc. } \\
\text { Kibun Co., Inc. }\end{array}$ \\
\hline Meats & $\begin{array}{l}\text { Beef jerky } \\
\text { Beef steak } \\
\text { Smoked beef } \\
\text { Spareribs (pork) } \\
\text { Smoked chicken } \\
\text { Ham (pork) } \\
\text { Frankfurter } \\
\text { Hamburger (without bread) }\end{array}$ & $\begin{array}{l}\text { Suzusho Co., Inc. } \\
\text { Hungry Tiger Co., Inc. } \\
\text { Kinokuniya Co., Inc. } \\
\text { Hungry Tiger Co., Inc. } \\
\text { Jokki Co., Inc. } \\
\text { Ito Ham Co., Inc. } \\
\text { Lomayer Co., Inc. } \\
\text { Marushin Foods Co., Inc. }\end{array}$ \\
\hline Eggs & Tamago tofu (egg curd) & Kinokuniya Co., Inc. \\
\hline Nuts and Beans & $\begin{array}{l}\text { Peanut } \\
\text { "Naturath" (processed food from } \\
\text { soybean proteins) }\end{array}$ & $\begin{array}{l}\text { Mameyoshi } \\
\text { Ajinomoto Co., Inc. }\end{array}$ \\
\hline Cereals & $\begin{array}{l}\text { French bread } \\
\text { English muffin } \\
\text { Nann } \\
\text { Steamed rice } \\
\text { Baked rice cake A } \\
\text { Baked rice cake B (containing waxy } \\
\quad \text { corn starch and nonglutinous rice) }\end{array}$ & $\begin{array}{l}\text { Saint-gelmain Co., Inc. } \\
\text { Saint-gelmain Co., Inc. } \\
\text { Kanda Seiyoken Co., Inc. } \\
\text { Echigo Confectionery Co., Inc. } \\
\text { Yukiguni Mochi Honpo }\end{array}$ \\
\hline Potato and Starches & $\begin{array}{l}\text { Dried sweet potato } \\
\text { Kuzu mochi (Starch jelly) } \\
\text { Imo yokan. (sweet potato paste) }\end{array}$ & $\begin{array}{l}\text { Hiraisoya Shyoten } \\
\text { Sumiyoshi Co., Inc. } \\
\text { Funawa Head Office Co., Inc. }\end{array}$ \\
\hline Vegetables and Fruits & $\begin{array}{l}\text { Raw carrot } \\
\text { Pickled radish } \\
\text { Apple ("Sun fuji") }\end{array}$ & $\begin{array}{l}\text { Grown in Chiba Prefecture } \\
\text { Kagoshima Tukemono Co., Inc. } \\
\text { Grown in Akita Prefecture }\end{array}$ \\
\hline Confectioneries & $\begin{array}{l}\text { Toddler biter biscuit } \\
\text { Marie biscuit } \\
\text { Crisp bread } \\
\text { Rice cracker } \\
\text { Hardtack } \\
\text { Caramel } \\
\text { Toffee } \\
\text { Kelp candy } \\
\text { Gummy candy }\end{array}$ & $\begin{array}{l}\text { Gerber Products Co., Inc. } \\
\text { Morinaga Confectionery Co., Inc. } \\
\text { Kanda Seiyoken Co., Inc. } \\
\text { Arano Confectionery Co., Inc. } \\
\text { Sanritsu Confectionery Co., Inc. } \\
\text { Sanesu Co., Inc. } \\
\text { Lotte Co., Inc. } \\
\text { Hokkai Daiichi Co., Inc. } \\
\text { Katjes Fassin GmbH + Co, KG }\end{array}$ \\
\hline
\end{tabular}

score sheet consisted of a series of five point category scales bounded at each end by a pair of antonym adjectives (Table II). Foodstuffs were standardized ( $15 \mathrm{~mm}$ height) as much as possible. The weight of each test foodstuff ingested by each panelist was $2 \sim 18 \mathrm{~g}$. Each sensory score was calculated from the average value of 5 subjects. Before each sensory test, all subjects ate the same foodstuffs to diminish deviation of scores obtained on each experimental day. One kind of fish cake obtained commercially was used as the standard sample. The instrumental score of its' 
Table II. RESPONSE FORM USED FOR SCORING THE FOODSTUFFS

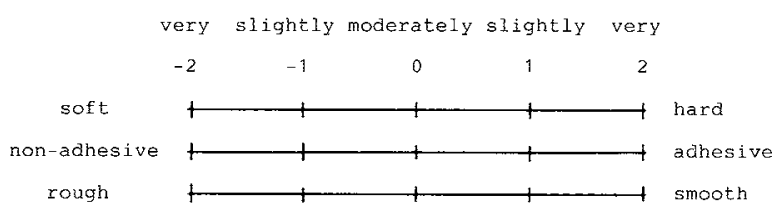

hardness (H1) was $3.59 \pm 0.21 \mathrm{~kg}$ (Mean \pm S.D.) using the Tensipressor (Model TTP - 50BX, Taketomo Electric Co., Ltd.). The experimental conditions were described previously. ${ }^{7)}$

Experimental subjects. Four subjects, 2 males and 2 females, 24 to 34 years of age, participated in the EMG measurements. They had no protheses and were free from clinical signs and symptoms of stomatognathic system.

Electromyographic measurement. The method consisted of direct and integrated EMG recording from the masseter and digastric muscles. These are the main chewing muscles; the former works during closing of the mouth or occluding and the latter works during opening of the mouth. Two pairs of Medicotest surface electrodes $(11 \mathrm{~mm}$ in diameter) were used to obtain EMG information from these muscles. These electrodes were placed on the masseter and digastric muscles by the covering of the muscles at intervals of $2 \mathrm{~cm}$. The natural chewing side of the subjects (right side in this case) was chosen for measurements. A reference electrode was placed on the right ear lobe (Fig. 1). Electromyographic recordings were made using a Polygraph System 361 (Nippon Denki Sanei Co., Inc.). The amplifying sensitivity was set up $0.2 \mathrm{mV}$ per $10 \mathrm{~mm}$ and time constant was $0.01 \mathrm{sec}$. The time base on the integrator module was set at $0.1 \mathrm{sec}$. Foodstuffs were standardized $(15 \times 15 \times 15 \mathrm{~mm})$ as much as possible with exceptions like dried squid and peanuts. For those exceptions the amount which subjects could chew naturally on the right side were measured. There were no foodstuffs any subject disliked. Between 1 and $3 \mathrm{~g}$ of each foodstuff was used in the EMG experiments. Every subject was asked to try to concentrate chewing efforts on the right side of the mouth. EMG recordings were continued until the test foods were swallowed. To recover from fatigue by chewing and to have the taste diminished, we had long enough intervals between chewing foodstuffs. Each subject had 5 or 6 foodstuffs a day.

Figure 2 represents some direct waves for the masseter muscle, together with the integral of all the waves shown. These are from the first chew to the seventh chew during the eating of a fish cake. The area of integrated waves as a single burst was measured with a digitizer. For each experiment, a control measurement was carried out using gum base $(2 \mathrm{~g})$ with no taste. The area per burst of the gum base was calculated from the average value in 10 to $40 \mathrm{sec}$.

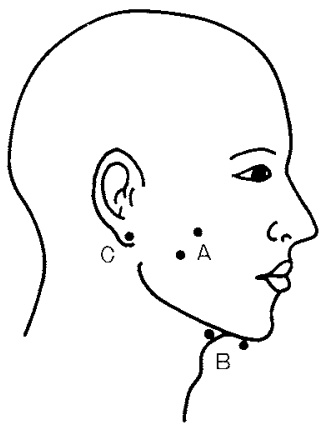

Fig. 1. Position of Electrodes Attached to Masseter Muscle and Digastric Muscle.

A, electrodes for masseter muscle; B, electrodes for digastric muscle; $\mathrm{C}$, reference electrode.

The ratio of the area of the foodstuff to that of the control gum base during chewing was calculated and then defined as the chewing energy as a single burst. Total chewing energy was represented by the sum of the chewing energy from the first chew to immediately before swallowing. These two parameters (chewing energy and total chewing energy) and the number of strokes were used to get information relating to the change of state of the foods during chewing. The parameters for the digastric muscle were obtained in a similar manner.

Analysis of variance was applied to the EMG data. Each value of chewing energy of each stroke was plotted on the $Y$-axis according to the number of strokes of the $X$ axis (Fig. 3).

$$
\begin{aligned}
& r=\left\{\sum(x i-\bar{x})(y i-\bar{y})\right\} / N \delta x \delta y \\
& x i=\text { Stroke number } \\
& \bar{x}=\text { Mean of } \mathrm{xi} \\
& y i=\text { Chewing energy } \\
& \bar{y}=\text { Mean of } y i \\
& N=\text { Total number of strokes } \\
& \delta x=\text { Standard deviation of stroke number } \\
& \delta y=\text { Standard deviation of chewing energy }
\end{aligned}
$$

Total area under the regression line of $y i$ on $x i$ were calculated for the masseter muscle and digastric muscle, respectively (Am and Ad). These total areas were defined as the total chewing energy. The values of "Am", "Ad" and the number of strokes were chosen as the parameters. They were used for the analysis of variances of data 
Masseter muscle

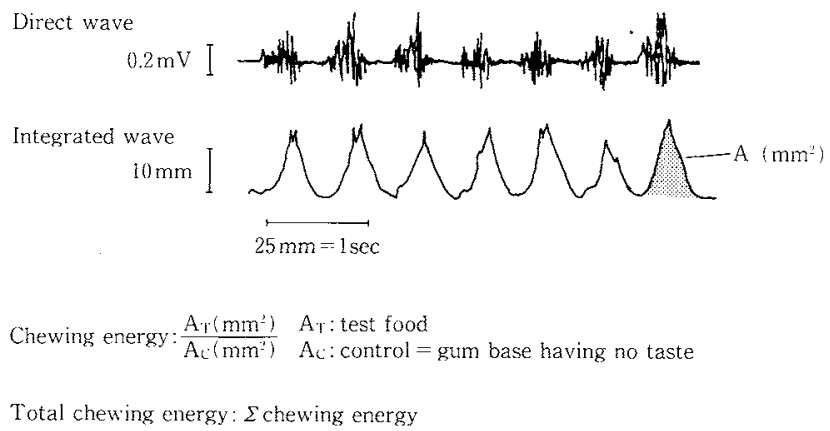

Fig. 2. Analytical Procedure Used for Chewing Energy.

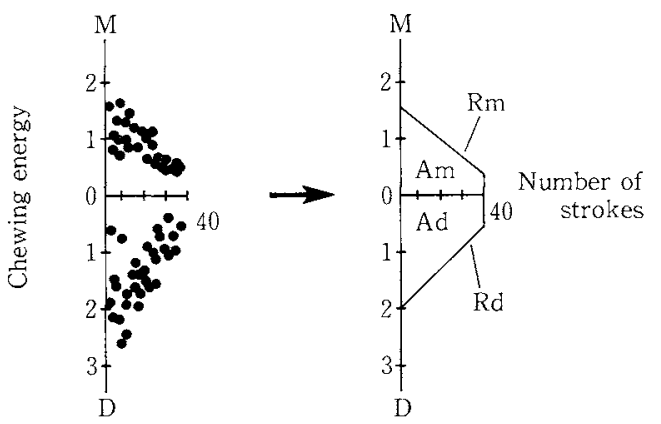

Fig. 3. Definition of the Total Chewing Energy Which Were Used for the Analysis of Variance of Data Obtained from Four Subjects.

Am, total chewing energy for masseter muscle; Ad, total chewing energy for digastric muscle; $\mathrm{Rm}$, regression line of the plots of chewing energy for masseter muscle; Rd, regression line of the plots of chewing energy for digastric muscle; $\mathrm{M}$, masseter muscle; D, digastric muscle.

among the four subjects. Multiple regression analysis was used to obtain the corrected values for total chewing energy.

Masticatory index. The masticatory index was measured according to the procedure of Ishihara. ${ }^{14 /}$ Each subject masticated $2 \mathrm{~g}$ of raw rice. The masticating side was same as the electromyographic measurement (right side). After various numbers of chewing strokes $(10,20$ and 30$)$, the masticated rice grains were expectorated over a screen (sieve aperture: $1.0 \mathrm{~mm}$ ). The fragmented particles were washed and dried. $\mathrm{Wt} \%$ over size of the screen were measured for each number of strokes. Masticatory index was calculated from the formula as follows.

$a=-1 / X \times \log Y / 100$

$X$ : Number of strokes during chewing of raw rice $Y: \mathrm{Wt} \%$ over size of the screen
The masticatory index was represented as the mean of all calculated values from each number of strokes.

Salivary flow rate. Salivary flow rate was measured according to the procedure already described by Kowata et al. ${ }^{7}$ Unilateral parotid saliva was collected with a modified Lashley vacuum cup held in place over the orifice of the parotid duct in the cheek by simple suction. The secreted saliva was collected via Tygon tubing attached to the suction cup.

Each subject chewed gum base with no tasts $(2 \mathrm{~g})$ for 30 seconds on the right side of the mouth, and the salivary flow rate was measured.

\section{Results and Discussion}

The sensory attributes of foodstuffs

The sensory scores for three attributes of foodstuffs are shown in Table III. Great differences were obtained in their texture score, i.e., soft and hard, smooth and rough, and nonadhesive and adhesive.

\section{Total chewing energies for foodstuffs}

Total chewing energies for one female subject are presented in Fig. 4. The vertical axis indicates the energy for the masseter muscle, which works during mouth closing and occlusing. The horizontal axis indicates the energy for the digastric muscle, which works during mouth opening. The total chewing energy of foodstuffs varied from 3 to 108 for the masseter muscle 13 to 154 for the digastric muscle. Significant differences among foodstuffs can be identified from plots of the total chewing energy. The energy observed during chew- 
Table III. Sensory Attributes and Electromyographic Patterns of Foodstuffs

\begin{tabular}{|c|c|c|c|c|}
\hline \multirow{2}{*}{ Name of foodstuff } & \multicolumn{3}{|c|}{ Sensory score } & \multirow{2}{*}{$\begin{array}{c}\text { Patterns } \\
\text { of chewing } \\
\text { energy }\end{array}$} \\
\hline & Hardness & Adhesiveness & Smoothness & \\
\hline Dried squid & 1.8 & -0.6 & 0.2 & $\mathrm{~A}$ \\
\hline Smoked scallop & 0.5 & -0.25 & -0.25 & A \\
\hline Smoked bonito & 0.6 & 0.6 & -1.2 & $\mathrm{~B}$ \\
\hline Smoked cuttlefish & 1.2 & 0 & 0 & - \\
\hline Jellyfish & 1.1 & -0.9 & 0.4 & A \\
\hline Raw squid & 1.0 & 0 & 0.9 & $\mathrm{D}$ \\
\hline Parched small sardine & 0 & -0.4 & -1.2 & - \\
\hline Sardine jerky & 1.0 & -0.2 & -0.8 & - \\
\hline Surimi sausage & -0.75 & -0.75 & 0.75 & $\mathrm{D}$ \\
\hline Tsumire & -0.2 & -0.6 & -0.2 & $\mathrm{D}$ \\
\hline Fish cake & 0 & -1.0 & -1.0 & $\mathrm{D}$ \\
\hline Beef jerky & 2.0 & -0.2 & -1.4 & $\mathrm{E}$ \\
\hline Beef steak & 1.4 & 0 & -1.6 & - \\
\hline Roast beef & 0 & -0.75 & -0.25 & - \\
\hline Spareribs (pork) & -1.2 & -0.6 & -1.0 & - \\
\hline Smoked chicken & 1.0 & 0.5 & -1.5 & A \\
\hline Ham (pork) & -0.3 & -1.0 & 1.0 & D \\
\hline Frankfurter & 0.2 & -0.2 & -0.4 & $\mathrm{D}$ \\
\hline Hamburger & -1.7 & -0.3 & -1.0 & $\mathrm{D}$ \\
\hline Tamago tofu & -1.9 & -1.3 & 1.8 & - \\
\hline Peanut & 1.0 & 0.6 & 0 & $\mathrm{E}$ \\
\hline "Naturarth" & -0.7 & -0.3 & -0.7 & $\mathrm{D}$ \\
\hline French bread & -1.2 & 1.0 & -0.6 & $\mathrm{~B}$ \\
\hline English muffin & -0.6 & 0.4 & -0.8 & $\mathrm{~F}$ \\
\hline Nann & 0 & 1.0 & -1.2 & $\mathrm{~F}$ \\
\hline Steamed rice & -1.4 & 0.6 & -0.2 & $\mathrm{~F}$ \\
\hline Baked rice cake $\mathrm{A}$ & -1.3 & 1.7 & 0.7 & $\mathrm{~F}$ \\
\hline Baked rice cake $B$ & -1.2 & 1.6 & 0.4 & $\mathrm{~F}$ \\
\hline Dried sweet potato & 1.2 & 1.0 & -0.2 & $\mathrm{~B}$ \\
\hline Kuzumochi & -0.6 & 0.5 & 0.8 & - \\
\hline Imo yokan & -0.9 & 0.9 & 0.3 & $\mathrm{~F}$ \\
\hline Raw carrot & 1.0 & -1.3 & -0.3 & $E$ \\
\hline Pickled radish & 1.0 & -1.0 & -0.5 & $\mathrm{E}$ \\
\hline Apple & 1.0 & -1.3 & -0.3 & $\mathrm{E}$ \\
\hline Toddler biter biscuit & 1.4 & 0.8 & -0.6 & $\mathrm{E}$ \\
\hline Marie biscuit & 0.4 & 1.2 & -0.4 & $\mathrm{E}$ \\
\hline Crisp bread & 0.4 & 0.4 & -1.5 & $\mathrm{E}$ \\
\hline Rice cracker & 1.8 & 0.4 & -1.2 & $E$ \\
\hline Hardtack & 1.2 & 0.8 & -1.4 & $\bar{E}$ \\
\hline Caramel & 1.4 & 2.0 & 0.5 & $\mathrm{C}$ \\
\hline Toffee & 0.6 & 1.6 & 0 & $\mathrm{C}$ \\
\hline Kelp candy & 1.4 & 1.2 & 0.8 & $\mathrm{C}$ \\
\hline Gummy candy & 1.4 & 1.0 & 0.8 & $\mathrm{~B}$ \\
\hline
\end{tabular}

A, B, C, D, E, F, pattern of chewing energy shown in Fig. 6; - , indistinct pattern.

ing of caramel and dried squid were extremely large. On the other hand, the energy during the chewing of imoyokan and kuzu-mochi gels had much lower values than caramel or dried squid. Thus, great difference were detected among foodstuffs which had observed variances in their texture.

It is said that there is a recent tendency towards an increase in the number of soft processed foods. Actually, the total chewing 


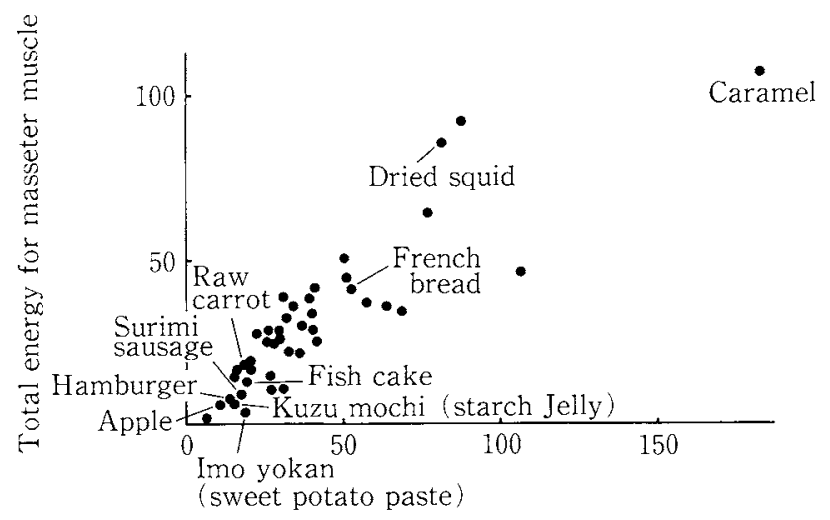

Total energy for digastric muscle

Fig. 4. Plots of Total Chewing Energy for 43 Foodstuffs (position for one female subject; F1).
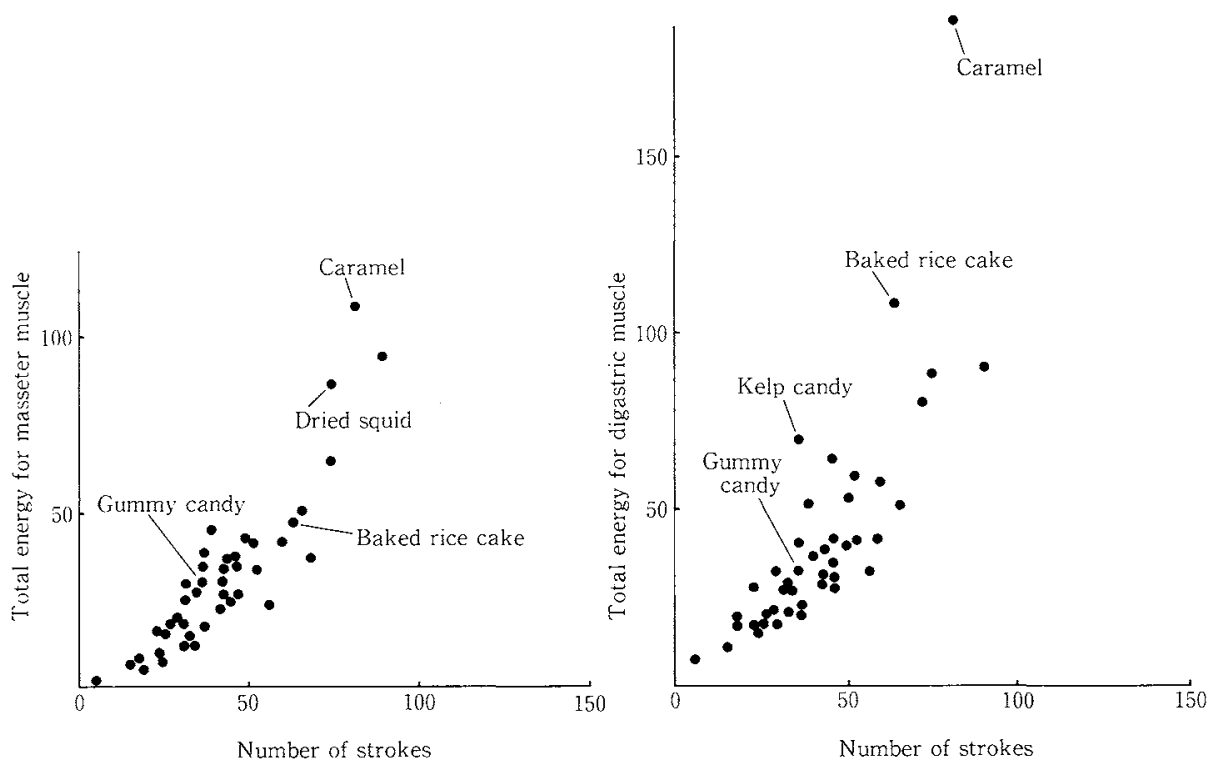

Fig. 5. Relationship between Total Chewing Energy and Number of Chewing Strokes (position for one female subject; F1).

energies for many processed foods were found to be low; examples include fish cake, surimi sausage, and kuzu-mochi (starch jelly). On the other hand, French bread (without crust) was found to require more total chewing energy than the fish cake, although it was perceived as softer than fish cake by the sensory test (Table III). In comparison with the French bread, the total chewing energy for raw carrot and apple was found to be less, even though they were perceived as harder than French bread.

The correlations between total chewing en- ergy and the number of strokes are shown in Fig. 5. It was observed that the great the total chewing energy for masseter muscle, the more the number of strokes needed for mastication up to swallowing. This correlation was also observed for the digastric muscle. There were some foodstuffs which the total chewing energy were same level, but the numbers of strokes were different among those. It was indicated that the total chewing energy was not only affected by the number of strokes. Caramel, baked rice cake, and kelp cangy were 
A) Smoked scallop

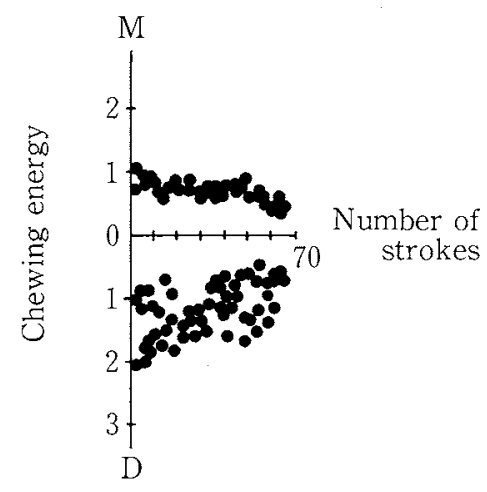

D) Fish cake

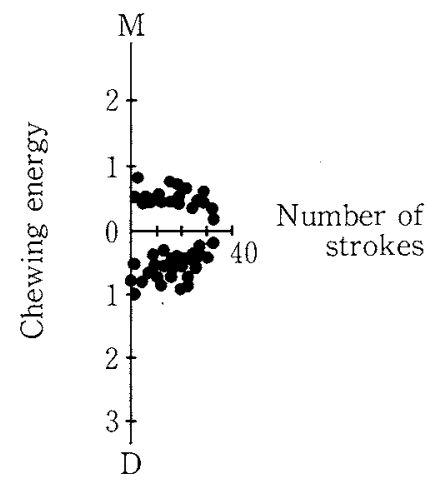

B) Gummy candy

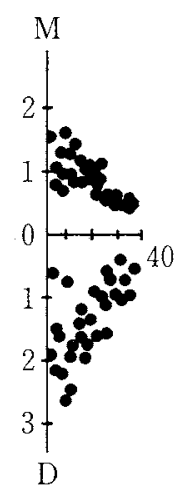

E) Toddler biter biscuit

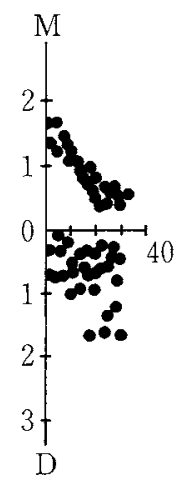

C) Caramel

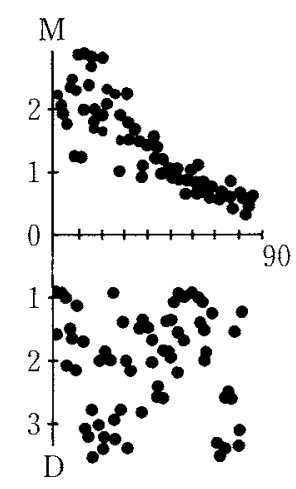

F) Baked rice cake

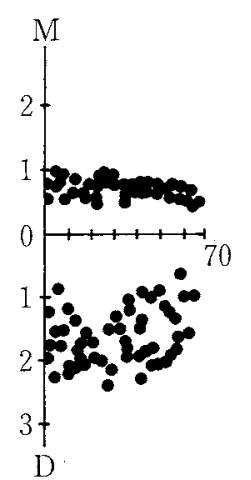

Fig. 6. Typical Patterns of Chewing Energy (plots for one female subject; F1).

$\mathrm{M}$, masseter muscle; $\mathrm{D}$, digastric muscle.

found to require large amounts of the total chewing energy for the digastric muscle; these data were not in accord with correlations observed for other foodstuffs. This result could be due to the differences in the degree of adhesiveness of these foodstuffs which required more chewing energy during mouth opening.

\section{Chewing energy for foodstuffs during chewing}

The chewing energy for foodstuffs revealed distinct differences throughout the chewing process. Every stroke was plotted on the vertical axis according to the stroke number of the horizontal axis. The chewing energies for the masseter muscle are shown in the upper half and for the digastric muscle are shown in the lower half of the each figure (Fig. 6). The typical six patterns of chewing energy were observed. The six patterns of chewing energy for smoked scallop, gummy candy, caramel, fish cake, toddler biter biscuit, and baked rich cake are shown respectively in Fig. 6 . Foodstuffs can be categorized into six groups according to the patterns of chewing energy (Table III). While kelp candy and gummy candy showed similar sensory scores, the patterns of chewing energy were different. Jellyfish and pickled radish showed similar score of hardness and adhesiveness, but they belonged to a different pattern of chewing energy.

During chewing smoked scallop, the level of the chewing energy for masseter muscle during 

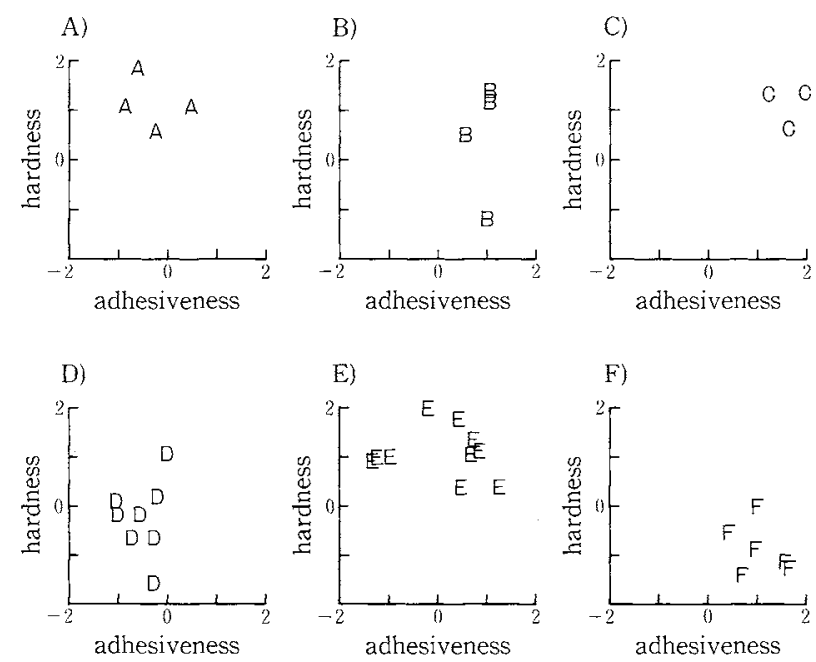

Fig. 7. Relationship between Sensory Score (hardness and adhesiveness) and Pattern of Chewing Energy. A, B, C, D, E, F, patern of chewing energy.

chewing was close to that for the first bite. It showed only a slight reduction throughout chewing. The chewing energy for digastric muscle was about one half that of the first bite and showed some variance during chewing. However, the degree of change in chewing energy toward swallowing was as little as the masseter muscle. On the other hand, in the case of gummy candy, the chewing energy for the masseter muscle on the first bite was much bigger than that with the gum base. This high energy level was maintained during several chewing strokes and then fell rapidly. The caramel showed a similar pattern to that of the gummy candy for the masseter muscle, but the level of the energy was higher than that for the gummy candy. The chewing energy for digastric muscle showed a different pattern. On the first bite, the chewing energy required was less than two times and then rose up to more than three times that of gum base. Fish cake showed a similar pattern to smoked scallop. However, the level of the chewing energy and the number of strokes were less than that for the smoked scallop. Toddler biter biscuit showed a pattern for masseter muscle similar to that of gummy candy. However, the degree of change during chewing for digastric muscle were not as great. Baked rice cake showed a pattern for masseter muscle similar to that of smoked scallop, but the level of the chewing energy for digastric muscle was larger than that with the smoked scallop.

The gummy candy, which was described as very hard and adhesive in the sensory test, showed a rapid decrease in hardness and adhesivess after several chewing strokes. The changes of chewing energy for this foodstuff seemed to come from its textural characteristics; the texture changed with salivary secretion and thermal degradation in the mouth. During chewing the caramel, the chewing energy for the digastric muscle which opens the mouth was very large. This result reflected the textural characteristic of caramel; it became very adhesive with saliva. The pattern of chewing energy for the toddler biter biscuit possibly reflected the change in its condition; on the first bite, the texture was very hard, but, during mastication, it broke down and mixed with saliva for swallowing. These patterns of chewing energy thus showed the textural characteristics of foodstuffs. The relationship between sensory score and the pattern of chewing energy was shown in Fig. 7. Foodstuffs categorized into $\mathrm{C}$ pattern had the highest score of adhesiveness. On the other hand, foodstuffs categorized in to $\mathrm{A}$ and $\mathrm{D}$ patterns had the 
Table IV. Total Chewing Energy and Number of Strokes for Foodstuffs

\begin{tabular}{|c|c|c|c|c|}
\hline \multirow{2}{*}{ Name of foodstuff } & \multirow{2}{*}{$\begin{array}{l}\text { No. of } \\
\text { subject }\end{array}$} & \multicolumn{2}{|c|}{ Total chewing energy } & \multirow{2}{*}{$\begin{array}{c}\text { Number of } \\
\text { strokes }\end{array}$} \\
\hline & & (Masseter) & (Digastric) & \\
\hline \multirow[t]{4}{*}{ Dried squid } & F1 & 84.6 & 78.4 & 73 \\
\hline & $\mathrm{F} 2$ & 106.5 & 61.1 & 83 \\
\hline & M1 & 41.8 & 32.9 & 42 \\
\hline & M2 & 77.8 & 47.7 & 65 \\
\hline \multirow[t]{4}{*}{ Smoked scallop } & $\mathrm{Fl}$ & 36.5 & 59.2 & 61 \\
\hline & $\mathrm{F} 2$ & 39.2 & 39.3 & 48 \\
\hline & MI & 40.0 & 41.5 & 48 \\
\hline & M2 & 67.7 & 49.0 & 76 \\
\hline \multirow[t]{4}{*}{ Smoked bonito } & $\mathrm{F} 1$ & 46.5 & 24.7 & 69 \\
\hline & $\mathrm{F} 2$ & 29.1 & 32.8 & 35 \\
\hline & Ml & 29.9 & 61.0 & 35 \\
\hline & M2 & 25.3 & 19.1 & 45 \\
\hline \multirow[t]{4}{*}{ Fish cake } & $\mathrm{F} 1$ & 17.3 & 20.2 & 36 \\
\hline & $\mathrm{F} 2$ & 12.7 & 20.5 & 34 \\
\hline & M1 & 4.2 & 7.3 & 19 \\
\hline & M2 & 6.5 & 7.9 & 27 \\
\hline \multirow[t]{4}{*}{ Peanut } & $\mathrm{F} 1$ & 37.4 & 30.6 & 41 \\
\hline & $\mathrm{F} 2$ & 25.5 & 24.7 & 28 \\
\hline & M1 & 22.1 & 27.3 & 30 \\
\hline & $\mathrm{M} 2$ & 17.1 & 19.1 & 28 \\
\hline \multirow[t]{4}{*}{ French bread } & $\mathrm{Fl}$ & 38.0 & 46.4 & 46 \\
\hline & $\mathrm{F} 2$ & 31.2 & 39.6 & 49 \\
\hline & $\mathbf{M} 1$ & 24.1 & 32.2 & 30 \\
\hline & $\mathbf{M} 2$ & 23.3 & 28.4 & 45 \\
\hline \multirow[t]{4}{*}{ Baked rice cake $A$} & $\mathrm{~F} 1$ & 38.0 & 77.3 & 51 \\
\hline & $\mathrm{F} 2$ & 17.0 & 25.8 & 31 \\
\hline & M1 & 25.9 & 29.6 & 27 \\
\hline & M2 & 21.6 & 29.6 & 41 \\
\hline \multirow[t]{4}{*}{ Imo yokan } & $\mathrm{F} 1$ & 3.3 & 12.5 & 21 \\
\hline & $\mathrm{F} 2$ & 4.3 & 12.4 & 15 \\
\hline & M1 & 4.2 & 12.4 & 14 \\
\hline & M2 & 4.3 & 10.5 & 15 \\
\hline \multirow[t]{4}{*}{ Raw carrot } & $\mathrm{Fl}$ & 17.0 & 16.7 & 24 \\
\hline & $\mathrm{F} 2$ & 29.0 & 31.7 & 47 \\
\hline & M1 & 10.0 & 9.7 & 27 \\
\hline & $\mathrm{M} 2$ & 22.0 & 17.9 & 39 \\
\hline \multirow[t]{4}{*}{ Toddler biter biscuit } & $\mathrm{F} 1$ & 28.5 & 20.9 & 36 \\
\hline & $\mathrm{F} 2$ & 30.0 & 34.1 & 30 \\
\hline & M1 & 20.6 & 27.8 & 36 \\
\hline & M2 & 30.3 & 28.6 & 45 \\
\hline \multirow[t]{4}{*}{ Caramel } & $\mathrm{F} 1$ & 107.5 & 154.0 & 88 \\
\hline & $\mathrm{F} 2$ & 82.7 & 126.0 & 96 \\
\hline & Ml & 56.3 & 126.0 & 72 \\
\hline & M2 & 36.8 & 74.4 & 58 \\
\hline \multirow[t]{4}{*}{ Gummy candy } & $\mathrm{F} 1$ & 33.3 & 46.3 & 46 \\
\hline & $\mathrm{F} 2$ & 40.3 & 43.9 & 51 \\
\hline & M1 & 24.8 & 22.7 & 30 \\
\hline & M2 & 23.1 & 25.4 & 36 \\
\hline
\end{tabular}

F1, F2, female subject; M1, M2, male subject. 
highest score of nonadhesiveness. It may be considered that the patterns of chewing energy indicate adhesiveness in sensory attributes. However, they can not be measured objectively with instruments, such as an instron or universal testing machine.

\section{Total chewing energy and number of strokes for four subjects}

Table IV presents the total chewing energy and number of strokes for four subjects in response to the selected 12 foodstuffs. It was recognized that there were significant variances among the data for foodstuffs, similar to the data observed from the one female subject. To inspect the variability among subjects, the total chewing energy for each subject was plotted in response to each foodstuff (Figs. 8-1, 8-2, 8-3). For several foodstuffs, i.e. dried squid and caramel, it was observed that there were large variances among subjects.

\section{Masticatory index and salivary flow rate}

To investigate factors of these variation of results of individual subjects, masticatory index and salivary flow rate were measured. The masticatory index seemed to be an important factor in evaluating the capacity of the human masticatory system. This method determines the particle size of the chewed food. The results of the masticatory index and salivary flow rate for each subject are shown in Table $V$. There were significant variances among the individual subjects.

\section{Regression analysis among EMG data, the mas-} ticatory index and salivary flow rate

Regression analysis was done among the EMG data (total chewing energy, number of strokes), the masticatory index, and salivary flow rate. For the regression analysis, the total chewing energy and the number of strokes for each subject were calculated by averaging of values for the 12 foodstuffs. The results are shown in Table VI. The total chewing energy and the number of strokes were highly correlated with the masticatory index. The larger the masticatory index of the subject, the less
Table V. Masticatory Index and Salivary Flow RATE

\begin{tabular}{ccc} 
Subject & $\begin{array}{c}\text { Masticatory } \\
\text { index }^{a} \\
\times 10^{-2}\end{array}$ & $\begin{array}{c}\text { Salivary flow } \\
\text { rate }^{b} \\
(\mathrm{~m} 1 / \mathrm{min})\end{array}$ \\
\hline F1 & 0.70 & 0.7 \\
F2 & 0.86 & 1.0 \\
M1 & 2.26 & 0.7 \\
M2 & 1.71 & 2.3 \\
\hline
\end{tabular}

a $-1 / X \times \log Y / 100$

$X$ : Number of strokes during chewing of raw rice $(2 \mathrm{~g})$

$Y: \mathrm{Wt} \%$ over size of the screen (sieve aperture: $1.0 \mathrm{~mm})$.

$b$ Unilateral parotid salivary flow during chewing of gum base $(2 \mathrm{~g})$

Table VI. Correlation COEfFicients for VARIOUS FACTORS

\begin{tabular}{lccr}
\hline & \multicolumn{2}{c}{ Total chewing energy $^{a}$} & \\
\cline { 2 - 3 } & $\begin{array}{c}\text { Masseter } \\
\text { muscle }\end{array}$ & $\begin{array}{c}\text { Digastric } \\
\text { muscle }\end{array}$ & \\
& -0.99 & -0.95 & -0.86 \\
& -0.21 & -0.57 & 0.19 \\
\hline Masticatory index & & &
\end{tabular}

a Total chewing energy, $\sum$ chewing energy.

Table VII. Regression Equations for Corrected Total Chewing Energy Based on Value FOR EACH SUBJECT

$$
\begin{aligned}
& Y_{\mathrm{m}}=5.43 \times X_{1} \times X_{2}{ }^{0.374} \times X_{3}{ }^{-0.0275} \quad R=0.999 \\
& Y_{\mathrm{d}}=2.19 \times X_{1} \times X_{2}{ }^{0.174} \times X_{3}{ }^{0.483} \quad R=0.999
\end{aligned}
$$

the total chewing energy and the number of strokes needed for mastication up to swallowing. The total chewing energy for the digastric muscle correlated with the salivary flow rate of the subject. The higher the salivary flow rate of the subject, the less the total chewing energy 
Position by observation

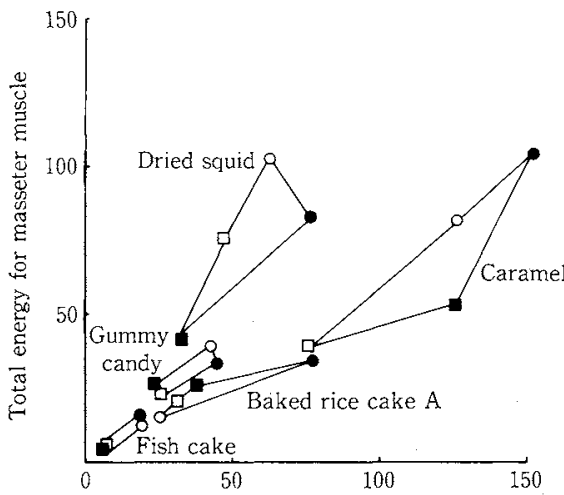

Total energy for digastric muscle
Position after correction

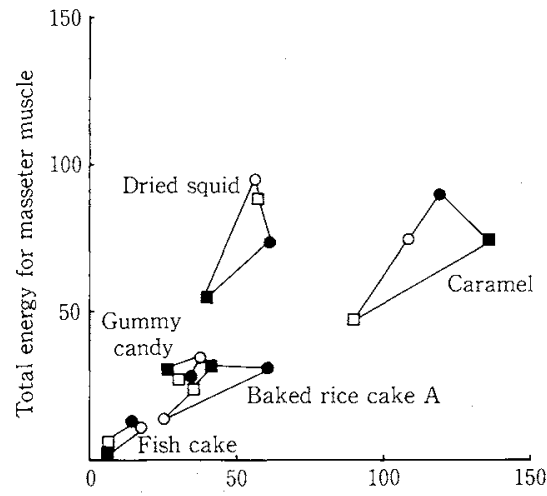

Total energy for digastric muscle

Fig. 8-1

Position by observation

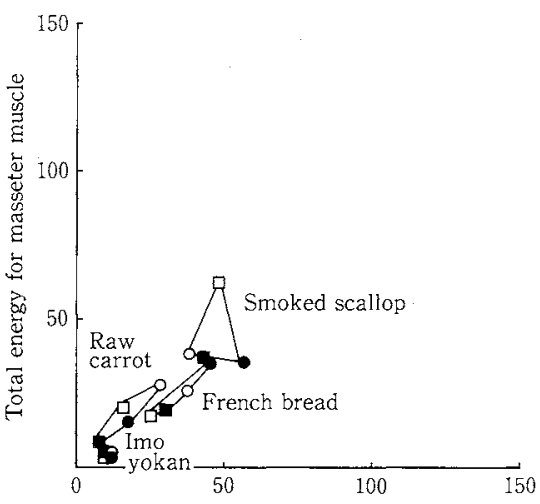

Total energy for digastric muscle
Position after correction

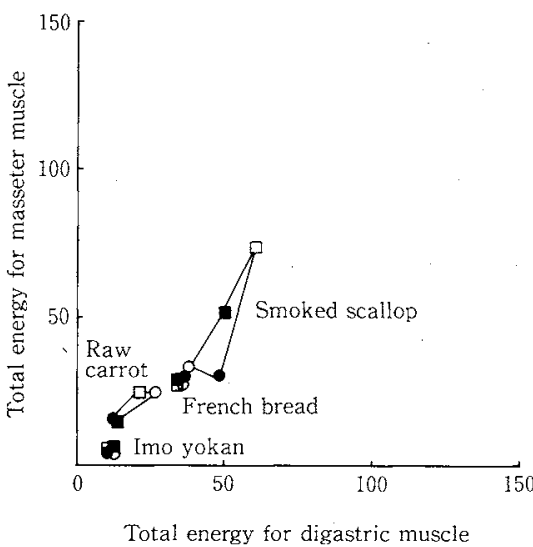

Fig. 8-2

Position by observation

Position after correction

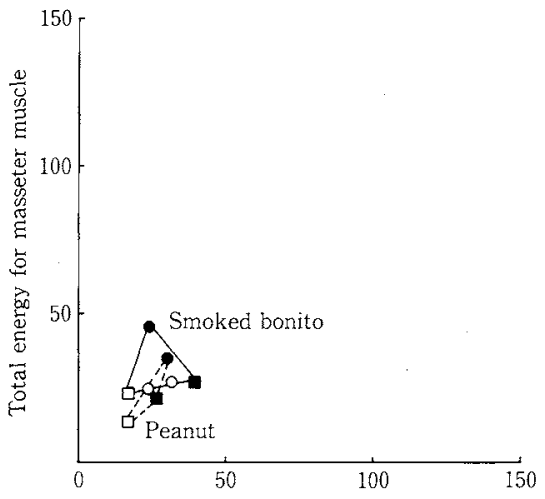

Total energy for digastric muscle

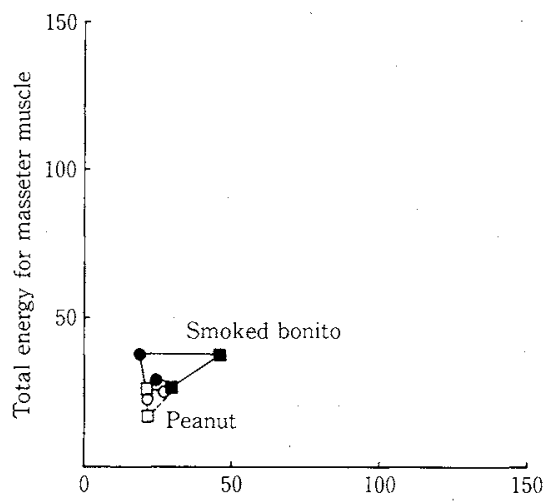

Tota! energy for digastric muscle

Fig. 8-3

Fig. 8-1 3. Total Chewing Energy for Each Subject (position for 12 foodstuffs).

F1 (○), F2 (O), female subject; M1 ( $\square)$, M2 ( $\square)$, male subject. 
for digastric muscle needed for mastication. From these results, it appeared that the total chewing energy and the number of strokes might be influenced by masticatory index and salivary flow rate for individual subjects.

We then attempted to reduce the variations in total chewing energy for individual subjects. Multiple regression analysis was done among the total chewing energy, masticatory index, and salivary flow rate. These analyses indicated that there were high correlations between total chewing energy and masticatory index and also between total chewing energy and salivary flow rate for individual subjects. Regression equations for the mean of the total chewing energy based on three values for individual subjects (total chewing energy, masticatory index and salivary flow rate) are given in Table VII. The mean of the total chewing energy for all four subjects could be predicted by using these equations and values for each subject.

The corrected positions and the observed ones were plotted for comparison in Figs. 8-1, 8-2, 8-3. Each corrected position was determined by using the measured total chewing energy with EMG, masticatory index, and salivary flow rate for each subject. With these correction analyses, the variation of the total chewing energy for individual subjects could be reduced as compared with the observed values.

The results of this study showed that the chewing energy varied quite widely with the textural characteristics of foodstuffs. Analyses using EMG to evaluate the characteristics of foodstuffs have been reported by Tamura $e t$ al. ${ }^{9)}$ and Siono et al. ${ }^{10)}$ However, they measured only total chewing energy; they didn't measure the masseter and digastric muscles separately. In addition, they used many soft foodstuffs, but few hard ones. Horio et al. ${ }^{11,12)}$ and Nakamura ${ }^{13)}$ reported the influence of texture on EMG values, but they didn't take into account the changes of chewing energy during chewing.

Boyar et al. ${ }^{3)}$ reported that EMG values while chewing gelatin gels and carrageenan gels revealed differences throughout the chewing process. But they measured only the masseter muscle. In our study, foodstuffs with varying textural characteristics were used. The chewing energies were analyzed for the masseter and digastric muscles separately. In addition, the pattern of chewing energy during chewing for each muscle was analyzed respectively. With these analyses, the differences in patterns of chewing energy among foodstuffs could be observed; furthermore, it became possible to observe the sensory texture characteristic during chewing.

Considerably more experimental work is needed to reduce the variation of individual subjects. In this study, there were some differences of physical form, moisture content, and taste among foodstuffs. More experimental work is needed with foodstuffs having the same physical forms, moisture content, and taste to better understand the observation of textural characteristics during chewing.

Conventional techniques can not measure the changes of textural perception. However, we have shown that it is possible by using EMG. This work will be expanded to describe texture objectively and control the texture of processed foods without sensory analysis which involves time, cost, and many panelists.

\section{References}

1) Z. M. Vickers and C. M. Christensen, J. Text. Stud., 11, 291 (1980).

2) A. S. Szczesniak, J. Text. Stud., 18, 1 (1987).

3) M. M. Boyar and D. Klicast, J. Food Sci., 51, 859 (1986).

4) J. G. Montejano, D. D. Hamann and T. C. Lanier, J. Text. Stud., 16, 403 (1985).

5) E. Tornberg, S. Fjelkner-Modig, H. Ruderus, P. Glantz, K. Randow and D. Stafford, J. Food Sci, , 50, 1059 (1985).

6) M. M. Boyar and D. Klicast, J. Text. Stud., 17, 221 (1986).

7) H. Kowata, T. Harada, T. Matsukubo and Y. Takaesu, Nippon Eiyō Shokuryō Gakkaishi, 40, 299 (1987) (in Japanese).

8) J. Ahlgren and B. Öwall, Archs Oral Biol., 15, 271 (1970).

9) A. Tamura, Y. Yanagisawa, Y. Teramoto and M. Akasaka, Japanese J. Pedodontics, 23, 984 (1985) (in 
Japanese)

10) K. Shiono, S. Kai, Y. Maruta, S. Hinotsume and T. Ogura, J. Dent. Hlth., 36, 179 (1986) (in Japanese).

11) T. Horio and Y. Kawamura, Jpn. J. Oral Biol, 30, 481 (1988).

12) T. Horio and Y. Kawamura, Jpn. J. Oral Biol, ,30,
524 (1988)

13) T. Nakamura, J. Osaka Univ. Dent. Soc., 32, 36 (1987).

14) T. Ishihra, Kōkū Byō Gakkaishi, 22, 207 (1955) (in Japanese). 